https://doi.org/10.25143/socr.15.2019.3.037-052

\title{
Religious Extremism as Social Phenomenon
}

\author{
Haki Demolli, Professor of Criminalistics \\ University of Prishtina, Kosovo \\ hakidemolli@yahoo.com
}

\begin{abstract}
There are numerous examples where political and religious contradictions have caused deep social crisis and disintegration of the state. It is true that the world is marked by new waves of violent extremism, radicalism and terrorism in the background of which are hidden religious, ethnic and ideological reasons. In reality, the reasons and activities of these groups are opposite to democratic and liberal values of tolerance and multiculturalism. Radicalisation leading to terrorism is a dynamic process in which a person is brought into a situation to accept terrorist violence as possible and justified actions of individuals and groups. The main goal of such violent actions is the achievement of political or religious objectives of such groups or individuals. The aim of this paper is to summarise the reasons that lead the individual to take the road of radicalisation, terrorism and extremism. Another aim of the paper is description and treatment of the ways of reacting of international community and individual states in prevention and fighting of extremism and terrorist activities.

Keywords: terrorism, religious extremism, violent extremism, terrorist radicalisation, terrorist groups and organisations, preventing terrorism and extremism.

\section{About religion}

Religion is the set of beliefs, feelings, dogmas and practices that define the relations between human being and sacred or divinity. A given religion is defined by specific elements of a community of believers: dogmas, sacred books, rites, worship, sacrament, moral prescription, interdicts, organisation. The majority of religions have developed starting from a revelation based on the exemplary history of a nation, of a prophet or a wise man who taught an ideal of life [7].
\end{abstract}


A religion may be defined with its three great characteristics: beliefs and religious practices; religious feeling, i.e. faith and unity in a community of those who share the same faith: the Church, the Mosque etc. It is what differentiates religion from magic [7].

The word religion is derived from Latin religio (what attaches or retains, moral bond, anxiety of self-consciousness, scruple) used by the Romans, before Jesus Christ, to indicate the worship of demons. The origin of religio is debated since antiquity. Cicero said it comes from relegere (to read again, to re-examine carefully, to gather) in the meaning "to carefully consider the things related to the worship of gods" [7].

There are an estimated 10,000 distinct religions worldwide, but about $84 \%$ of the world's population is affiliated with one of the five largest religions, namely Christianity, Islam, Hinduism, Buddhism or forms of folk religion. The religiously unaffiliated demographic includes those who do not identify with any particular religion, atheists and agnostics. While the religiously unaffiliated have grown globally, many of the religiously unaffiliated still have various religious beliefs.

\section{Definition of extremism}

In order to understand the essence of extremism, we begin with the etymology of the word itself. Extremism derives from the Latin word "extremus" and can be translated as extreme, intransigent in certain ideas, attitudes and actions. If we pay attention to the Latin term ad extrema, we will see that it can be defined as something that goes to the limit, just as human extremities - arms and legs - are endings on the human body.

According to the definition "extremism is vocal or active opposition to fundamental state values, including democracy, the rule of law, individual liberty and mutual respect and tolerance of different faiths and beliefs. Extremism also includes calls for death of members of the armed forces" [2].

\section{Abuse of religion}

It is clear that violence as evil does not belong to any religion. Religion condemns violence and considers it a distortion of human consciousness. In the theological sense, the source of evil, is not God.

Religion protects five fundamental values [3]: holiness of human life (God gives life and only He can take it away); freedom of religion; peace and merciful; equality among identity to different groups of people and stopped bloodshed among them and building of peace among themselves and to live peacefully with each other.

Religion is not the primary driver of violence, nor can it be understood as a kind of trigger, although in some cases it was brought into a relationship and it was noticeable. Given that in some instances the extremist group and individuals succeed in abusing religion and in it find the inspiration for the evil they do, conditionally, in some ways, religion is designated as the trigger of violent extremism. 
So, some of the most fatal attacks such as the terrorist attack on the United States on September 11, 2001, the terrorist bombing of a train in Madrid, the Anders Behring Breivik terrorist attack in Norway and, unfortunately, a large number of other such religiously motivated mass killings show how common abuse of religion to justify and encourage the killing and terrorising of people everywhere in the world. Historically, religion was also used as a "reason" to commit genocide against Jews in Europe.

Also, religion was at the heart of the intense war between Catholics and Protestants in France at the end of the $16^{\text {th }}$ century. About 3 million people were killed in fighting lasting more than 30 years [18].

\section{Causes of religious extremism}

\section{What causes the criminality in general?}

There are certain factors in our societies, cultures (family values), system (educational, political, law-enforcement, ...), economy, and so on that endorse the potential of criminal activities of an individual. Usually a combination of these factors is behind a person who commits a crime. Reasons for committing a crime include greed, anger, jealously, revenge, or pride. Some people decide to commit a crime and carefully plan everything in advance to increase gain and decrease risk. These people are making choices about their behavior; some even consider a life of crime better than a regular job - believing crime brings in greater rewards, admiration, and excitement - at least until they are caught. Others get an adrenaline rush when successfully carrying out a dangerous crime. Others commit crimes on impulse, out of rage or fear [3].

\section{What causes the religious extremism?}

In general there are different opinions about the causes of religious extremism, but we will address only some of the general concepts of factors that impose a person to deal with this unlawful, dangerous and extremely harmful activity for society.

In favor of this opinion is the thought of US Deputy Secretary of State Tony Blinken, who said "what we know is that there is no kind of violent extremism, which has a unique method of recruitment, a single source of motivation and support, no recipe. There are no simple synonyms that would be identified with one religion, religious tradition or culture ... Shorter, the nature and framework of possible drivers of violent extremism can vary to a great extent" [11].

According to Michelle Roya Rad [14], "there are many reasons behind why an average person may do something harmful to an innocent person while seeing it as a good deed. These reasons are multi-dimensional and to explain them in simple, tip-of-the iceberg terms will only add to the confusion, rather than bring meaningful understanding. Generally, a few of these reasons are the world's lack of a moderate, moral and fair role model, in addition to a lack of access to proper education in many places, 
lack of basic resources for many people, too much repression, autocratic rulers, closed minded and egocentric leaders, personality factors, family upbringing, a tarnished sense of pride, among many others".

There may be a few general characteristics of people who turn into extremists [14]:

- They have a sense of absolutism: they have a distorted, non-constructive and irrational thought that the truth, moral or aesthetic values are absolute, universal, set and unchangeable. They do not believe in change and diversity and are usually very low in their tolerance level.

- They have a sense of righteousness: they usually think that they know the truth and no one else does. Their truth is very limited and based on outdated, contaminated and one-sided information. They usually do not even have enough knowledge about their own religion and only know the surface part.

- They do confirmation bias: this is where one only brings in information that fits his thought process and dismisses anything else. Any other information, no matter how historically, scientifically and logically valid, will be disregarded.

- They have a sense of knowing an ultimate meaning: they have a sense of a black and white thinking where the white is a limited definition of how life "should" be for all of us. There is no flexibility, no adaptability and no objectivity. You are either into this small and specific white zone or you are "the other".

- They dehumanise whoever does not fit their view: they put other people's views inferior to theirs and dehumanise people whose views do not fit theirs. This gives them a sense that they have the right to kill, harm and destroy others. They also do the same to out-groups.

- They idolise historic figures or stories: such people usually idolise some figures in their belief system and stories attached to the past and want to fit the present and the future into that idolisation.

- They have an utter certainty that they are right: the objective mind of a rational person knows that at any time, there are so many things he does not know. But an extremist does not have such view and holds a distorted thought that he knows all the answers and has found the "truth" which is the only truth.

- They have a sense of unwillingness to compromise: for such individuals, there is only one way and that is what matches their definition of truth. They are not willing to find common grounds with other people and cannot find win-win positions.

- They have too much focus on the life after death: a religious extremist has too little focus on the importance of this life and what makes him feel fulfilled in it and is too attached to the concept of a "great" afterlife.

- They have many psychological defenses: such individuals have formed a number of psychological defenses so none of their internal feelings would be challenged.

But other views on the factors of religious extremism are confronted in a study of a concrete terrorist act related to religious extremism. There were conducted many 
debates, after the terrorist attacks on September 11, 2001, whose goal was to answer the question of the causes of violent extremism and radicalism. Some answers were crystallised mainly in the sense that the possible factors of the cause were: poverty, hopelessness and ideology.

\section{Some of the measures taken by the global community and various nations to combat religious extremism}

Targeting extremism is about targeting ideas more than individuals. There should be a significant concern about the rise of extremists with this populated world. This is our future as it defines whether humanity will have peace or a devastating conflict that will cost all of us tremendously. If there is any war, it should be a collective and universal war against extremist through education, knowledge and information.

However, which are the measures practically taken by society in general and states in particular to prevent and combat the phenomenon of religious extremism? Initially we would point out the measures that the European Parliament has foreseen in one of its resolutions approved in 2015. The European Parliament based on facts that more than 5,000 European citizens joined terrorist organisations and other military units, and in particular ISIS (Daesh), Jabhat al-Nusra and others outside the European Union, particularly in the Middle East and North Africa; since this phenomenon is increasingly accelerating and taking on considerable proportions; and fact that the notion of radicalisation is used to describe the phenomenon within which people accept intolerant opinions, views and ideas that may cause violent extremism; and other relevant facts, has approved: The Resolution of November 25, 2015 on the Suppression of Radicalisation and Recruitment of European Citizens in Terrorist Organisations (2015/2063 (INI)).

With this Resolution, the European Parliament, among others in the fight against religious extremism, also foresees these measures:

- preventing violent extremism and terrorist radicalisation in prisons;

- preventing terrorist radicalisation on the internet;

- prevent radicalisation by education and social inclusion;

- better exchange of information on terrorist radicalisation in Europe;

- improvement of deterrence from terrorist radicalisation;

- preventing the departure and anticipation of the return of radicalised European citizens recruited by terrorist organisations;

- strengthening the links between the internal and external security of the EU;

- encouraging the exchange of good practices in deratisation;

- abandonment of terrorist networks.

On the other hand, the General Assembly of UN on February 12, 2016, adopted a resolution that "welcomes the initiative by the Secretary-General, and takes note of his Plan of Action to Prevent Violent Extremism". The General Assembly decided to "give further consideration to the Plan of Action to Prevent Violent Extremism beginning in 
the Global Counter-Terrorism Strategy review in June 2016 as well as in other relevant forums". The Assembly concluded its general debate on the plan of action to prevent violent extremism on February 16, 2016.

In the Plan, the Secretary-General calls for a comprehensive approach encompassing not only essential security-based counter-terrorism measures but also systematic preventive steps to address the underlying conditions that drive individuals to radicalise and join violent extremist groups. The Plan is an appeal for concerted action by the international community. It provides more than 70 recommendations to Member States and the United Nations System to prevent the further spread of violent extremism.

In this Plan of Action, among others in the fight against religious extremism, also are foreseen these measures:

- creation of a global framework for preventing violent extremism;

- national plans of action for preventing violent extremism;

- regional plans of action to prevent violent extremism;

- mobilising resources;

- supporting member states, regional bodies and communities through the United Nations;

- taking action - recommendations in 7 key areas:

o dialogue and conflict prevention;

○ strengthening good governance, human rights and the Rule of Law;

$\circ$ engaging communities;

○ empowering youth;

$\circ$ gender equality and empowering women;

o education, skill development and employment facilitation;

o strategic communications, the internet and social media.

Except international organisations, also individual states that are confronted with religious extremism, they have foreseen and defined various measures in the fight against religious extremism. For example, Bosnia and Hercegovina in their strategy [4] against terrorism, have foreseen among others, these measures.

\section{Preventive measures:}

- Develop a system of early identification of all forms of extreme behaviour that can lead to terrorism.

- Develop a positive communication strategy and actively work with the media to promote it.

- Promote values of democracy, the rule of law, tolerance and dialogue - create specific educational programmes for young people through curricula and extracurricular activities.

- Support activities of citizens and civil society organisations aimed at preventing hatred and promoting positive narratives (opposing violent extremist narratives by highlighting positive examples of social values, tolerance, openness). 
- Support inter-religious dialogue and activities carried out by the Inter-Religious Council (Bosnian).

- Streamline and assist the academic community in continuing to investigate terrorism, hate crimes, hate speech and other security emergencies in society, with the aim of identifying key problems and developing and advancing preventive measures.

- Strengthen the role of the so-called social corrections from family, through social services, to education and other services.

- Prevent vulnerable people and groups to choose violent extremism and terrorism as a means of achieving their goals.

- Create synergies within the framework of local communities on the relationship between the public sector - the religious community.

- Cooperate with citizens and civil society organisations, work of police in the community, develop specific security programmes for vulnerable local communities, place special emphasis on increased participation of local religious leaders, young people and women. [17]

\section{Protection measures from religious extremism:}

- Create the biometric data collection system fully into the visa issuance process.

- Create the biometric data collection system and take biometric data from the Foreign Service Department in the process of residence permitting and issue expulsion measures against foreign nationals and make it operational and accessible for use by security agencies.

- Improve Information Migration System and make it operational and accessible for use by security agencies.

- Improve the Visa Information System and make it fully operational.

- Bind security databases.

- Fully implement international standards in the domain of cyber security, especially those related to the establishment of CERT in Bosnia and mechanisms for monitoring and combating Internet abuse for terrorist purposes.

- Develop procedures for the analysis of controls and projects for improving the warehousing safety of weapons, military equipment, explosives and dualpurpose means, as well as their traffic through or through Bosnia. [4]

\section{Measures dealing with investigation and criminal persecution:}

- Improve the legislative framework for the fight against terrorism and violent extremism (harmonise it with international standards and harmonise those in criminal codes in Bosnia), including regulations regulating the area of control of movement and residence of foreigners. Ratify international instruments relevant to the fight against terrorism. 
- Improve the legal framework for coordinating all operational and investigative activities, collecting, analytical processing and information exchange.

- Strengthen human and material-technical resources for conducting operational and investigative activities.

- Strengthen international cooperation, countries in the region, countries of interest, with EUROPOL. EUROJUST and through the INTERPOL system.

- Analyse risks and develop repressive measures against, facilitate illegal access to weapons and explosives by violent extremists / terrorists.

- Prevent financing of terrorism by continuing to harmonise legislation according to the requirements of FATF ${ }^{1}$ and MONEYVAL ${ }^{2}$, and consistently apply other standards, in particular the obligation to conduct full financial investigations in the investigation of the acts of terrorism.

- A special focus on acts related to the Criminal Actions of Terrorism is to undertake investigative activities in the direction of crossing the channel of illegal trade in weapons and explosives and other materials that may serve to commit terrorism. [17]

\section{Some examples of religious extremism, where religious belief has used religion as a mean to justify violence and acts of aggression to cause territorial integrity or political independence}

Unfortunately, throughout history, but also in the contemporary world, certain organisations, who have attempted to accomplish their political and material aims through violence, have acted by justifying that they are using the same (violence) to protect certain religious values. So simply, they abused religion, justifying the use of violence, by calling on certain religious values.

According to terrorism expert David C. Rapoport, a "religious wave", or cycle, of terrorism, dates from approximately 1979 to the present. According to Rapoport, this wave most prominently features Islamic terrorism, and also includes terrorism by Christians and other religious groups that may have been influenced by Islamic terrorism [15].

1 The Financial Action Task Force (FATF) is an inter-governmental body established in 1989 by the Ministers of its Member jurisdictions. The objectives of the FATF are to set standards and promote effective implementation of legal, regulatory and operational measures for combating money laundering, terrorist financing and other related threats to the integrity of the international financial system. The FATF is therefore a "policy-making body" which works to generate the necessary political will to bring about national legislative and regulatory reforms in these areas.

2 MONEYVAL is a permanent monitoring mechanism of the Council of Europe, a pan-European organisation with 47 member states, reporting directly to its principal organ, the Committee of Ministers. 
Groups, respectively such extremist religious organisations, operate in different countries and continents of the world.

In the continuation of this article the existence and the infamous activity of some of them will be noted.

\section{Islamic extremists}

The highest numbers of incidents and fatalities caused by Islamic terrorism occur in Iraq, Afghanistan, Nigeria, Pakistan and Syria. In 2015, four Islamic extremist, groups were responsible for $74 \%$ of all deaths from terrorism: ISIS, Boko Haram, the Taliban and Al-Qaeda [8].

To better understand the activity, scope, goals, tools and methods, as well as the existence of an extremist religious organisation, we will give some of the features of the Boko Haram organisation, operating mainly in Nigeria.

The name of the organisation itself "Boko Haram" that in translation means "Western Civilization is a sin" indicates the nature, aims and objectives of the organisation, which is primarily denial respectively intolerant towards Western civilization. The group's main goal is to establish an Islamic caliphate within the country, which would allow for the implementation of sharia law. Boko Haram is fighting to overthrow the government and create an Islamic state [10].

Boko Haram is a branch of the Islamic State of Iraq and the Levant. Mohammed Yusuf founded the sect that became known as Boko Haram in 2002 in Maiduguri, the capital of the north-eastern state of Borno. He established a religious complex and school that attracted poor Muslim families from across Nigeria and neighbouring countries. It has been active in Nigeria since 2003. The group is active in the north of Nigeria and wants to impose Islamic law as the only law in Nigeria [19].

Islamist group Boko Haram has caused havoc in Africa's most populous country through a wave of bombings, assassinations and abductions. It is estimated that the Boko Haram Organisation in the period 2003-2018, has committed hundreds of terrorist acts, attacks on churches and other similar actions, resulting in the death and injury of thousands of mostly non-Muslim persons, then kidnapping thousands of children, girls, women and sexual abusing of a large number of them.

\section{Christian extremists}

Ilaga, is a Catholic Extremist group that is anti-Islam based in southern Philippines. The group is predominantly composed of Visayans (mostly Ilonggo), embracing a form of Folk Catholicism that utilizes amulets and violence. From March 1970 to January 1972, the Ilaga committed 22 massacres resulting in the deaths of hundreds of Muslim civilians. The group is guilty of "mutilating bodies of victims" and "marking bodies with a cross". It also burned down and looted many houses and properties. The group committed its bloodiest act on June 19, 1971, when the group killed 70-100 Moro civilians inside a mosque. [12] 
Anti-balaka groups destroyed almost all mosques in the Central African Republic unrest. In 2014, Amnesty International reported several massacres committed by the Antibalaka against Muslim civilians, forcing thousands of Muslims to flee the country. Other sources report incidents of Muslims being cannibalised. While anti-balaka groups have been frequently described as Christian militias in the media, this has been denied by Church leaders. Bishop Juan José Aguirre said: "But in no sense can it be said that the antibalaka is a Christian group. The anti-balaka are made up of people of all kinds, terribly enraged, and including many people whom we call the 'dispossessed' - bandits, exprisoners, delinquents, criminals - who have got involved in these groups and are now extending, like a plague of locusts, across the whole of the CAR, murdering Muslims." [4]

The Nationalist Socialist Council of Nagaland (NSCN) is also a Christian Naga nationalist militant group operating in North India. The main aim of the organisation is to establish a sovereign Christian state, "Nagalim", unifying all the areas inhabited by the Naga people in Northeast India and Burma. The organisation's slogan is "Nagaland for Christ".

Maronite Christian militia perpetrated the Karantina and Tel al-Zaatar massacres of Palestinians and Lebanese Muslims during Lebanon's 1975-1990 civil war. The 1982 Sabra and Shatila massacre, which targeted unarmed Palestinian refugees for rape and murder, was considered to be genocide by the United Nations General Assembly. A British photographer present during the incident said that "people who committed the acts of murder that I saw that day were wearing [crucifixes] and were calling themselves Christians". [5]

The Walisongo school massacre is the name given to a series of attacks by Christian militants on May 28, 2000 upon several predominantly Muslim villages around Poso town, Central Sulawesi, Indonesia as part of a broader sectarian conflict in the Poso region [5].

Orthodox Christian-influenced movements in Romania, such as the Iron Guard and Lăncieri, which have been characterised by Yad Vashem and Stanley G. Payne as anti-semitic and fascist, respectively, were involved in the Bucharest programme and political murders during the 1930's [5].

The Russian Orthodox Army (The ROA), is a Christian Extremist militant group in Ukraine that was founded in May 2014, as part of the insurgency and following War in Donbass. Along with other separatist groups in the region, the ROA has been noted of "kidnapping, beating, and threatening Protestants, Catholics, and members of the Ukrainian Orthodox Church ... as well as participating in anti-Semitic acts" [16].

\section{The Jewish religious extremists}

It has been suggested that a similarity between Jewish religious terrorists and jihad networks in Western democracies is their alienation and isolation from the values of the majority, mainstream culture, which they view as an existential threat to their own community. 
Terror Against Terror (Hebrew: Terror Neged Terror, TNT) was a radical Jewish militant organisation that sponsored several attacks against Palestinian targets. The group was founded by Rabbi Meir Kahane's Kach organisation, and took its name from Kahane's theory that Arab terrorism should be met with Jewish terrorism [4].

\section{The Buddhist religious extremists}

Buddhism is generally seen as among the religious traditions least associated with violence, but in the history of Buddhism there have been acts of violence directed, promoted, or inspired by Buddhists. As far as Buddha's teachings and scriptures are concerned, Buddhism forbids violence for resolving conflicts.

In recent years the State Peace and Development Council (SPDC), the military regime of Burma from 1988 to 2011, had strongly encouraged the conversion of ethnic minorities, often by force, as part of its campaign of assimilation. The regime promoted a vision of Burmese Buddhist nationalism as a cultural and a political ideology to legitimise its contested rule, trying to bring a religious syncretism between Buddhism and its totalitarian ideology

Myanmar had become a stronghold of Buddhist aggression and such acts are spurred by hardline nationalistic monks. The oldest militant organisation active in the region is Democratic Karen Buddhist Army (DKBA), headed by a Buddhist monk U Thuzana, since 1992. In the recent years the monks, and the terrorist acts, are associated with the nationalist "969 Movement" particularly in Myanmar and neighboring nations. The violence reached prominence in June 2012 when more than 200 people were killed and around 100,000 were displaced. As of 2012, the "969 Movement" by monks (the prominent among whom is Wirathu) had helped create anti-Islamic nationalist movements in the region, and have urged Myanmar Buddhists to boycott Muslim services and trades, resulting in persecution of Muslims in Burma by Buddhist-led mobs. However, not all of the culprits were Buddhists and the motives were as much economic as religious. On June 20,2013, Wirathu was mentioned on the cover story of Time (magazine) as "The Face of Buddhist Terror". According to the Human Rights Watch report, the Burmese government and local authorities played a key role in the forcible displacement of more than 125,000 Rohingya people and other Muslims in the region. The report further specifies the coordinated attacks of October 2012 that were carried out in different cities by Burmese officials, community leaders and Buddhist monks to terrorise and forcibly relocate the population. The violence of Meiktila, Lashio (2013) and Mandalay (2014) are the latest Buddhist violence in Burma. [6] 


\section{More about the act of the proscription of faith groups which use violence and acts of aggression to cause territorial integrity or political}

Bearing in mind the criminal activity of extremist religious groups, and in particular the harmful consequences for human beings, material goods, the intolerance, the uncertainty that they cause in the environments where such groups operate, and especially the high risk posed to the human society in general, different international organisations and certain states have decided to deny their existence, respectively to put out of the law, such organisations.

The proscriptions of antiquity and the middle ages serve to remind us that outlawing or banishing enemies of the state is a longstanding privilege of sovereignty.

The terminology of blacklisting, listing, designation, outlawing, banning orders, and more, are commonplace in the rubric of proscription.

\section{The legal framework for proscription of religious extremism groups}

Just two weeks after the September 11, 2001, attacks, the UN passed Security Council Resolution $1373 .{ }^{3}$ Although the UN made no attempt to define terrorism in the Resolution, and would not do so until 2004, it nonetheless provided that member states enact legislation to tackle the threat posed by a seam of seemingly ubiquitous violent islamic extremist organisations.

The Resolution stipulated that Member States should prevent and suppress the financing of terrorist acts; freeze financial assets connected to persons directly or indirectly connected to terrorists and enact or modify domestic criminal legislation to prevent persons within the state from providing financial or other support to terrorists. ${ }^{4}$

While UN Resolutions have no binding legal force, they nevertheless impose a 'normative obligation' on Member States and the response to Resolution 1373 was immediate.

States moved quickly to draft new legislation to comply with the UN's stricture: 1) Australia passed The Charter of the United Nations (Anti-Terrorism Measures) Regulations 2001 and The Security Legislation Amendment (Terrorism) Act 2002; 2) Canada passed Anti-Terrorism Act 2001; 3) The UK amended the TA 2000 with the Antiterrorism, Crime and Security Act 2001; and 4) The US enacted the Uniting and Strengthening America by Providing Appropriate Tools Required to Intercept and Obstruct Terrorism Act 2001 (USA PATRIOT Act).

\footnotetext{
${ }^{3}$ Resolution 1373 (2001), adopted by the Security Council at its $4385^{\text {th }}$ meeting, on September 28, 2001.

${ }^{4}$ It is foreseen in Article 1 (paragraphs a, b and c) of UN Resolution 1373 (2001).
} 


\section{What are the benefits of the proscription of extremist religious organisations?}

The formal designation of an organisation as terrorist: for instance, is a typical pre-requisite to the confiscation or freezing of that group's assets; or the prevention of its members from soliciting support; or the banning of an organisation running for political office, travelling across national borders, or using certain forms of transport.

Proscription, in short, is a fulcrum of states' counterterrorism capabilities and ambitions.

\section{The diversity and consequences of proscription regimes}

There is the diversity of political and legal settings that structure proscription regimes and their complex transnational interactions.

Consequences of proscription:

- Proscription as action or process has broader implications for national security, international organisations, fundamental liberal freedoms and for individuals connected to designated entities.

- The consequences for individuals can be severe, for example. Thus, where both the Australian and UK proscription regimes contain "status" offences relating to membership criminalising individuals for who they are, rather than what they have done Australia's powers grant prosecutors considerable latitude, specifying "informal" members as well those who have "taken steps to become a member" [9].

- In Turkey, for example, membership offences have been used as a means of suppressing domestic dissent and support for Kurdish separatism in which Kurds are, as Sentas argues in this issue, "routinely" prosecuted for crimes connected to the PKK or membership of the PKK on often spurious evidence. As she notes, the period of 2009 and 2013 alone saw nearly 40,000 such prosecutions [9].

\section{Lists of banned terrorist groups}

Most states in the international system, and a number of international governmental organisations (IGOs), maintain lists of banned terrorist groups. In the United States, for instance, the Secretary of State designates a list of Foreign Terrorist Organisations (FTOs); a list which contains 61 organisations. In the United Kingdom, it is the Home Secretary who has the power to proscribe an organisation believed to be engaged in terrorism (with the Parliament's consent). Seventy-one organisations are on this list. At the inter-state level, meanwhile, the European Union established its own "list of persons, groups and entities involved in terrorist acts and subject to restrictive measures" following the events of September 11, 2001. This list currently hosts 13 persons, and 31 groups and entities. [9] 


\section{The evaluation of the effectiveness \\ of proscription frameworks}

Regarding the effectiveness of the practical implementation of the legislation on the proscription of extremist organisations, there are different studies and opinions, some of which will be emphasized:

- In a review of the first five years of the proscription laws in Australia, the Inquiry into the proscription of 'terrorist organisations' under the Australian Criminal Code, found that 'Australia has listed nineteen organisations but so far proscription has not been an element in any of the prosecutions for terrorist organisation offences'.

- In her review of the UN's anti-terrorism measures, Bianchi [1] describes the prospect of assessing implementation of the measures as a 'daunting task', and notes that lawyers 'lack adequate parameters to objectively judge the efficacy of states' implementing measures as well as their consistency with other obligations incumbent on them'.

- The UK Independent Reviewer of Terrorism Legislation sought to determine the extent to which counter-terrorism laws had resulted in substantive prosecutions. In his report on The Terrorism Acts in 2012, he found that the UK government does not collate complete data on all offences brought in prosecutions of individuals under the sections 11 to 13 of the TA 2000: only 'principal offences' are recorded and reported. Since membership of a terrorist organisation might be a lesser charge than the principal offence in a prosecution, the Reviewer thus concluded it was 'impossible to know the full extent' to which proscription laws criminalising membership of a terrorist organisation had been used [9].

\section{Conclusions}

1. Religious extremism, as a dangerous phenomenon, is quite widespread in the contemporary world.

2. Some of the most fatal attacks such as the terrorist attack on the United States on September 11,2001, the terrorist bombing of a train in Madrid and unfortunately, a large number of other such religiously motivated mass killings show how common is abuse of religion from religious extremists.

3. In general there are different causes of religious extremism.

4. It should be a collective and universal war against extremist through education, knowledge and information.

5. The resolution of November 25, 2015 on the suppression of radicalisation and recruitment of European citizens in terrorist organizations (2015/2063 (INI)) and UN Plan of Action to Prevent Violent Extremism, also foresees a lot of measures against religious extremism. 
6. Except international organisations, also individual states that are confronted with religious extremism, have foreseen and defined various measures in the fight against religious extremism, one of such states is Bosnia and Hercegovina.

7. Bosnia and Hercegovina in their Strategy for Prevention and Fight against Terrorism (2015-2020), have foreseen among others, these measures: preventive measures; protection measures from religious extremism and measures dealing with investigation and criminal persecution.

8. Groups, respectively extremist religious organisations, operates in different countries and continents of the world. They are abusing almost all religions like, the Muslim religion, Christian, Jewish, Buddhist and others.

9. Different international organisations and certain states have decided to deny existence of the religious extremist groups, respectively to put them out of the law or their proscription.

10. Proscription of the religious extremist groups is based on legal framework, creates some benefits, has some consequences and his effectiveness is evaluated by different analysers and scientific workers.

\section{Reliǵiskais ekstrēmisms kā sociāls fenomens}

\section{Kopsavilkums}

Ir daudz piemēru, kur politiskās un religisiskās pretrunas izraisỉjušas dziḷu sociālo krīzi un valsts sabrukumu. Ir tiesa, ka pasauli iezīmē jauni vardarbīga ekstrēmisma, radikālisma un terorisma viḷni, kuru fonā ir slēpti reliǵiski, etniski un ideoloğiski iemesli. Vardarbīgas rīcības galvenais mērķis ir atsevišķu grupu vai indivīdu politisko vai reliǵisko mērḳu sasniegšana. Realitātē vardarbīgo grupu iemesli un darbība ir pretēja demokrātiskām un liberālām tolerances un multikulturālisma vērtībām. Radikalizācija, kas noved pie terorisma, ir dinamisks process, kurā rodas situācija, kad teroristu vardarbība tiek pieñemta kā iespējama un pamatota indivīdu un grupu rīcība. Viens no šā raksta mērḳiem ir apkopot iemeslus, kuru dēḷ indivīds dodas radikalizācijas, terorisma un ekstrēmisma virzienā, otrs raksta mērḳis - aprakstīt un noskaidrot veidus, kā reagèt uz starptautiskās sabiedrības un atsevišḳu valstu centieniem novērst un apkarot ekstrēmismu un teroristiskas darbïbas.

Atslēgvārdi: terorisms, reliğiskais ekstrēmisms, vardarbīgs ekstrēmisms, teroristu radikalizācija, teroristu grupas un organizācijas, terorisma un ekstrēmisma novēršana. 


\section{References}

1. Bianchi, A. (2006). Assessing the Effectiveness of the UN Security Council's Anti-Terrorism Measures: The Quest for Legitimacy and Cohesion. European Journal of International Law, 17(5), 881-919.

2. Canterbury Christ Church University. (2016). Government Definitions of extremism, radicalisation and terrorism. www.canterbury.ac.uk/university-solicitors-office/docs/governmentdefinitions-of-extremism-radicalisation-and-terrorism.pdf

3. Causes of Crime: Explaining Crime, Physical Abnormalities, Psychological Disorders, Social and Economic Factors, Broken Windows, Income and Education. https://law.jrank.org/pages/12004/ Causes-Crime.html

4. Christian Terrorism. (2018). Alchetron: Free Social Encyclopedia for the World. https://alchetron. com/Christian-terrorism.

5. Christian Terrorism. Infogalactic. https://infogalactic.com/info/Christian_terrorism

6. Huda, M. N. (August 30, 2017). Apartheid in Our Neighbourhood! The Daily Star (portal). https://www.thedailystar.net/opinion/straight-line/apartheid-our-neighbourhood-1455931

7. http://atheisme.free.fr/Religion/What-is-religion-1.htm

8. Institute for Economics and Peace. (2016). Global Terrorism Index 2016. https://reliefweb.int/ report/world/global-terrorism-index-2016

9. Jarwis, L. and Legrand, T. (2018). The Proscription or Listing of Terrorist Organisations: Understanding, Assessment, and International Comparisons. Terrorism and Political Violence, 30(2).

10. Kwame, N. P. Religious Militancy and Terrorism in West Africa: A Case Study of Political Islam. https://pdfs.semanticscholar.org/d21f/c79b3d694368b2a28768b1367dff37ed0237.pdf

11. Mandaville, P. \& Nozell, M. Engaging Religion and Religious Actors in Countering Violent Extremism. http://www.css.ethz.ch/en/services/digital-library/articles/article.html/c56482beb0ea-48a0-935b 6443e2379741/pdf

12. Mariveles, J. D. (February 14, 2015). Mindanao: A memory of massacres. https://www.facebook. com/notes/bangsamoro/mindanao-a-memory-of-massacres/1022765234417517/

13. Music, S. (2018). Religious Aspects of the Phenomenon of Violent Extremism. http:// en.globalanalitika.com/religious-aspects-of-the-phenomenon-of-violent-extremism

14. Rad, M. R. (2013). What Turns Ordinary People into Religious Extremists? https://www.huffingtonpost.com/roya-r-rad-ma-psyd/

15. Rapoport, D. C. (2013). The Four Waves of Modern Terror: International Dimensions and Consequences. https://www.researchgate.net/publication/286896869_The_four_waves_of_ modern_terror_International_dimensions_and_consequences

16. U.S. Department of State. (2015). International Religious Freedom Report for 2014.

17. Western Balkan Integrative Internal Security Governance. (2015). Strategy of Bosnia and Herzegovina for Preventing and Combating Terrorism. Sarajevo, 2015. https://wb-iisg.com/docs/ strategy-of-bosnia-and-herzegovina-for-preventing-and-combating-terrorism-2015-2020/

18. White, M. (January 2012). The Thirty Years War (1618-48). Necrometrics. https://necrometrics. $\mathrm{com} / \mathrm{pre1700a \cdot htm}$

19. Yayandi, M. B. (September 11, 2017). Terrorism in Nigeria: History of Boko Haram Attacks in Northeastern Nigeria and Their Collaboration with the World Terrorist Called "ISIL". https://www. globalethicsnetwork.org/profiles/blogs/terrorism-in-nigeria-history-of-boko-haram-attacks-in 